\title{
INTRODUCTION: The Monologue as CONVERSATION
}

\author{
PHILLIP LOPATE
}

THIS ESSAY COLLECTION, by some of the best literary minds of our time, took over fifteen years to distill into book form. Originally, each essay was delivered as a formal lecture to the Bennington College community, and was issued shortly afterward as a chapbook, in handsome isolation. The latecoming reader has a different, time-collapsed experience of these annual events, as though a slow, stately academic procession were suddenly speeded up and crunched together. Also missing is the erotics of a formal lecture, as the audience, Leda-like, waits with resignation and receptivity for its Zeus to descend and take hold, while the speaker mayhap suffers performance anxiety. In return, however, the reader gains the cumulative opportunity to distinguish, at leisure, patterns of thought, rhetorical strategies, and common themes as they pass from one speaker to another, to participate in the call-and-response of intellectual life at this historical period. For what began as a series of monologues has become a conversation.

It may seem odd that a school like Bennington, renowned for informality and a spirit of improvisation, has chosen to sponsor a blue-chip parade of veteran intellects. Indeed, I must confess that I approached this almost too-respectable enterprise at first with skepticism, so often do such celebrations of intellectual eminence disappoint. I am happy to testify, though, that the Belitt Lectures provide a feast of thinking; collectively, they represent a state-of-theart demonstration of the contemporary literary essay.

What unifies these fifteen singular voices is their passion for lit- 
erature and their ability to bring language to life through a mode of witty and provocative discourse, at once magisterial and epigrammatic. The panache of the mot juste is often memorable: "He went at full tilt into the sump of his teenage self, filling notebooks with druggy, bewildering lines that would be a kind of fossil fuel to him for years to come" (Seamus Heaney on the young Dylan Thomas). "Dying cultures make the best cultures" (Richard Ellmann on Decadence). "The most authentic of literary Sublimes has the Epicurean purpose of rendering us discontented with easier pleasures in order to prepare us for the ordeal of more difficult pleasures" (Harold Bloom on Whitman and Stevens). "In particular, you cannot create a character without thereby making a suggestion about how your reader should act" (Richard Rorty on the inextricable bonds of aesthetics and ethics).

It would seem that the formal circumstance of public address has called forth, in our fifteen critics, a highly developed exchange of ironic courtesies. That they have been summoned to deliver a Belitt Lecture is clearly an honor, acknowledging as it does a publicly successful literary career; and yet the scale of the event-an hour-long talk-limits the range of possibilities, inspires modesty, compression, doubt. That ironic play between modesty and ambition is, in fact, part and parcel of the essay form, as Georg Lukács pointed out. It

is at the root of that humor and that irony which we find in the writings of every truly great essayist. . . . And the irony I mean consists in the critic always speaking about the ultimate problems of life, but in a tone which implies that he is only discussing pictures and books, only the inessential and petty elements of real life-and even then not the innermost substance but only their beautiful and useless surface. . . . The essayist dismisses his own proud hopes which sometimes lead him to believe that he has come close to the ultimate: he has, after all, no more to offer than the explanations of the poems of others, or at best of his own ideas. But he ironically adapts himself to this smallness-the eternal smallness of the most profound work of the intellect in face of life-and even emphasizes it with ironic modesty. 
Alongside the "ironic modesty" in these talks is a sort of pull toward the nobility of belief. Here we must remember that the literary address is not merely synonymous with the literary essay: because it is delivered orally, in this case before an assembled academic community, it must take into consideration expectations that might not affect the purely written literary essay. The specific circumstances seem to invite one to assert conviction-a credo of sorts-and also to leave the youthful listener in an expectant, or at least not too lugubrious, mood. Indeed, many of the Belitt Lectures follow a "plot" of working from darkness and gnarled doubt toward something a bit more hopeful.

What is even more striking, in our secular age, is the frequency of religious, sacred-ceremonial, or even necromantic references peppering these essays. George Steiner, who delivered the first address, perhaps set the tone with his very moving invocation of the old-fashioned ritual of reading, presenting the "ceremonious encounter between reader and book" as a kind of sacrament. Denis Donoghue, citing the Book of John, discusses the divinity of the Word. Frank Kermode titles his playful essay "Divination," and analyzes the impact of variant readings on theology in Revelation 1:5. Hugh Kenner devotes his whole talk to "Magics and Spells," concluding thunderously that "only triviality can pretend that by its analytic habits magic has at last been superseded." Cynthia Ozick invokes the supernatural, "sacred terror" and Swedenborgian metaphysics in Henry James's background. Bernard Malamud calmly testifies like a professional alchemist: "In writing I had to say what had happened to me, yet present it as though it had been magically revealed." Ben Belitt, the self-described "pre-humous" eponym of the series, caps the matter with his brilliant investigation of three spiritual texts, asking "how is praise possible for the modern spirit, in a time of techniques, methodologies, and sciences which invite the skeptical manipulation of all the categories of thought and matter, and substitute cunning for awe?" Seamus Heaney is introduced as one for whom poetry is "priestly, the most sacred vocation."

Why this insistence on awe, priestliness, and magic in a series 
of literary talks? Is it a compliment to the host, Mr. Belitt, whose course at Bennington "Literature and Belief" is still legendary, and who, as one student testified, "taught us to conceive of all literature as a sacred endeavor"? Can it be that the formal academic lecture is itself a kind of religious rite, focusing the attention in a way akin to liturgical service? Or is learning seen as such endangered arcana in a post-literate age that the literary scholar finds himself identifying with the scholar-monk? The critic as Magus? Clearly, sacredness and literary vocation are somehow intertwined. As Irving Howe, in his meaty essay, "The Making of a Critic," remarks: "in a secular age literary criticism carries a heavy burden of intention, becoming a surrogate mode of speech for people blocked in public life."

It is not surprising that the summons to give the Belitt Lecture would occasion some retrospection about the mission of a literary career. Irving Howe is perhaps the most frankly personal in his assessment of how he became a literary critic (first, he says, by copying the styles of Orwell, Wilson, Rahv, and Trilling!), and the most candid about questions of status and competition in the literary life. He sees himself as part of a "rude" generation of insurgent Jewish intellectuals who punctured the decorum of literary discourse. "All you needed to be called a literary critic, it seemed, was a determination to read with charged attention and a pencil in the clutch of your fingers." Of course, Howe testifies, it did not prove so easy; but his image of the pencil-clutching arriviste irresistibly calls to mind George Steiner's gentler vocational definition: "The intellectual is, quite simply, a human being who has a pencil in his or her hand when reading a book."

The role of the intellectual, his or her obligations toward and questionable utility to modern society, are problems much vexed in these pages. Saul Bellow, one of a trio of practicing "creative writers" or, in any case, "non-literary" critics, tries to slip the noose by arguing emphatically that "artists cannot be described as intellectuals. The divergence first manifests itself in differences of language, for the language of intellectuals is the common language of the cog- 
nitions, whereas the languages of art are individual. Their uniqueness is a guarantee that they are genuine." The cerebral cognitions put forward in this passage, and in the essay as a whole, appear to contradict Bellow's point; here, at least, artist and intellectual would seem to be one and the same beast. But Bellow wryly apologizes for his penchant for ideas, saying "nobody wants to be a birdbrain."

If we look dispassionately at the particular group of critics and writers assembled here, we find they have much in common, which may help explain the intellectually coherent tone of the collection. They are men, with two exceptions (an imbalance we hope and suspect will be corrected in future years); and moreover, what used to be called "men of letters"- that is, free-ranging generalists and humanists, rather than the narrow academic specialist umbilically attached to one theory or another, who proliferates today in the study of literature. Half the Belitt lecturers are Jewish; a third, Irish. They are for the most part over sixty, and, in a sense, represent the end of a most eminent line of public intellectuals. That there is, for the moment, no guarantee that their ranks will be replenished by literary thinkers of equal stature and range may account for a note of melancholy valediction that creeps from time to time into these addresses. George Steiner mourns the loss of a middle ground between illiteracy and over-specialization; Bernard Malamud eyes "the resurgence of ignorance in our culture"; Saul Bellow warns that "Only the purest human consciousness, art consciousness, can see us through this time of nihilism."

Some of this pessimism undoubtedly reflects the personal circumstances of aging individuals staring into their own mortality. Here we might also cite what the storywriter Max Apple calls "the style of middle age," or biology at the level of syntax. In Apple's words: "The style of middle age is a style of reappraisal, a style characterized by hesitation, by uncertainty, by the objects of the world rather than the passions that transported us from this world. . . . When copulation loses her rough hold, when we have come near to the end of our reproductive lives, we hesitate. When we look past the body, we don't know what we'll find." 
Nowhere is the style of middle age more sensitively probed than in Cynthia Ozick's analysis of the turning, in Henry James's art, from the entertaining Victorian lucidities of the early period to the murkier modernist quandaries and gravities of the middle and late James. Ozick shows that "the awkward age" is as much a reference to the menopausal male as the adolescent female.

There is another reason for the reflective hesitancy in these essays. Are the fifteen essayists not, for the most part, spokesmen for the infamous DWEMs (dead white European males)? Besieged on the one hand by multiculturalists and feminists who would revolutionize the syllabus, and on the other hand by deconstructionists who would jettison the very notion of great literary texts and authorship, no wonder they express an occasionally embattled sense of aristocratic isolation. But this isolation generously includes us, somehow. Perhaps it is in the nature of giving an important literary address to invite the audience under the canopy of quality: "we," the privileged few, surrounded by the howling barbarians of popular culture who disdain our intellectual activity.

Politics and its troubled relations with aesthetics is another recurrent theme in these essays. Denis Donoghue lays out the ground of the age-old argument between word and deed, formalism and social activism. Showing how writers of both the Right and the Left have inveighed against the dominant bourgeois culture, Donoghue concludes: "It is time to say that the bourgeois liberal has a strong case, if he would make it." And he makes it. Nadine Gordimer - who has given so much to the struggle against racism in her country-argues that fiction's only morality is to "explore and examine" with "unafraid honesty," as she threads her way gracefully through the snares of fiction, morals, and politics. From the other end, the perils of excessive aestheticism are taken up by Richard Ellmann and Richard Rorty. Ellmann explores "decadence" as both cul-de-sac and escape route. Rorty reads sensitively past Nabokov's own mandarin pronouncements on aesthetic bliss, to uncover the caring, cruelty-hating, disappointed liberal-humanist underneath. Indeed, the liberal re-emerges in these 
essays as an heroic, if battered, proponent of political principles that have much in common with a sympathetically belle-lettristic approach to literary study.

René Girard takes apart Shakespeare's consummate political play, Julius Caesar, to demonstrate that Brutus is not so much Caesar's principled antagonist as his mimic, and that "the characters disagree because they agree too much." Girard also challenges the familiar, political reading of the play that says Shakespeare showed a "conservative" bias in his treatment of the mob: "The crisis turns not only the lower classes into a mob but the aristocrats as well. . . Our preoccupation with class struggle distorts our appreciation not only of Shakespeare but of tragic literature in general. Our virtuous defenders of the proletariat see only the symptoms that affect their protegés."

Ultimately, one of the greatest pleasures this collection affords is its strong, surprising readings of individual texts. I have already mentioned the Rorty, Girard, and Belitt analyses; I would like to add to the list the candor of Seamus Heaney's masterfully judicious reassessment of Dylan Thomas. In phrasing for us our own inner doubts about this sometimes bombastic and mechanically sentimental poet, then going on to show where and in which poems his genius lies, he performs an act of reclamation much more generous and effective than hagiographic criticism. Then there is Harold Bloom's powerful reading of Whitman's "When Lilacs Last in the Dooryard Bloom'd." Initially it seems outrageous and farfetched, his premise that Whitman was masturbating as he wrote this great work. But a second reading of this essay has convinced me that Bloom is uncannily right about some of this material, and in any case has entered more deeply into Whitman's consciousness than most of Walt's explicators.

Irving Howe's essay includes an affectionately savvy dissection of Lionel Trilling's rhetorical strategy: "Trilling would begin with a simulated hesitation but soon plant a hint that just ahead lay some revelation about the ways in which 'we'- 'the educated classes'were misconstruing 'the cultural situation." " Just so; it is interesting 
to figure out how each of the contributors to this collection adapts an essay strategy. Harold Bloom, who meanders through Bryant, Emerson, Hart Crane, and Stevens before tackling his main subject, lets us in on the joke: "Yet I am sneaking up on him, always the best way for any critic to skulk near the Sublime Walt." René Girard comes roaring out of the chute, demanding with rhetorical questions that we come quickly to the heart of the matter. Ben Belitt, alluding to Pascal's wager, lays down several preconditions for his argument, including the mischievously straight-faced "let us be somber." George Steiner begins with a painting, thereby triangulating his discourse between image, text, and listener. And so on. I would not want to spoil the reader's fun by giving away each maneuver in advance. It is enough to appreciate that we are watching masters of the game of essay-writing, who, even as they comment on the masterpieces of other writers, practice their own literary wizardry. 


\section{THE ORDERING MIRROR}




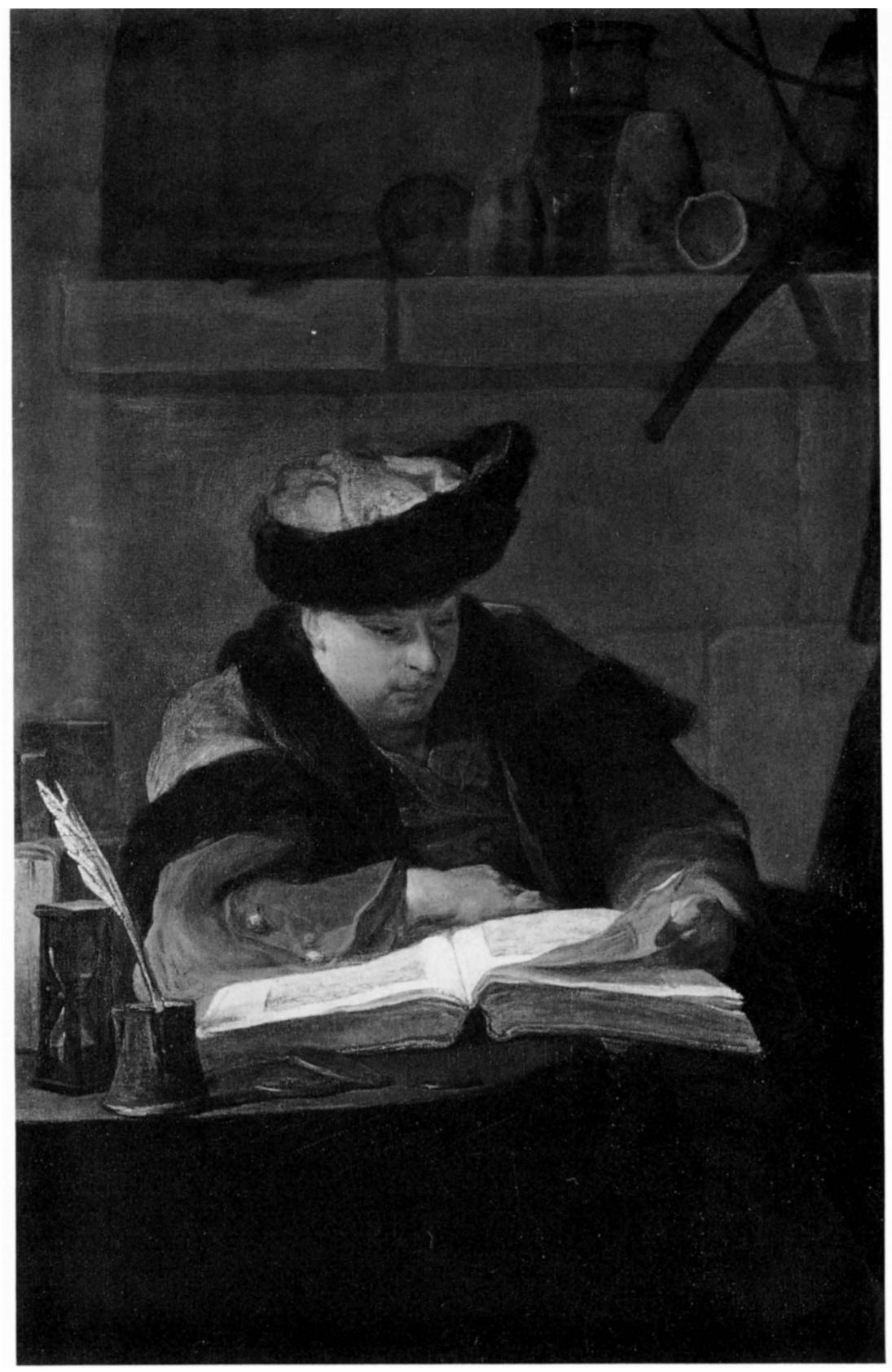

Le Philosophe lisant, by Jean-Siméon Chardin.

Musée du Louvre, Paris 